\title{
A Novel Nonenzymatic Hydrogen Peroxide Sensor Based on Magnetic Core-Shell $\mathrm{Fe}_{3} \mathrm{O}_{4} @ \mathrm{C} / \mathrm{Au}$ Nanoparticle Nanocomposite
}

\author{
Xiao Ni $\mathbb{D}$, Mingwei Tian, Jun Sun, and Xiaojun Chen $\mathbb{D}$ \\ College of Chemistry and Molecular Engineering, Nanjing Tech University, Nanjing 211800, China \\ Correspondence should be addressed to Xiaojun Chen; chenxj@njtech.edu.cn
}

Received 16 August 2020; Revised 25 January 2021; Accepted 22 February 2021; Published 8 March 2021

Academic Editor: Günther K. Bonn

Copyright (c) 2021 Xiao Ni et al. This is an open access article distributed under the Creative Commons Attribution License, which permits unrestricted use, distribution, and reproduction in any medium, provided the original work is properly cited.

$\mathrm{Fe}_{3} \mathrm{O}_{4} @ \mathrm{C} / \mathrm{Au}$ nanoparticle (AuNP) nanocomposites were prepared through electrostatic adsorption of AuNPs onto PDDAfunctionalized core/shell $\mathrm{Fe}_{3} \mathrm{O}_{4} @ \mathrm{C}$ magnetic nanospheres, which had been synthesized by a facile solvothermal method. The morphology and composition of the nanocomposites were characterized by transmission electron microscopy (TEM), scanning electron microscopy (SEM), Fourier transform infrared (FT-IR), etc. Moreover, highly electrocatalytic activity to the reduction of hydrogen peroxide $\left(\mathrm{H}_{2} \mathrm{O}_{2}\right)$ was also exhibited on the $\mathrm{Fe}_{3} \mathrm{O}_{4} @ \mathrm{C} / \mathrm{AuNP}$-modified indium tin oxide (ITO) electrode. The effect of solution $\mathrm{pH}$ and the modification amount of $\mathrm{Fe}_{3} \mathrm{O}_{4} @ \mathrm{C} / \mathrm{AuNPs}$ on the performance of electrocatalytic $\mathrm{H}_{2} \mathrm{O}_{2}$ reduction was investigated. Under the optimal conditions, the catalytic current showed a linear relationship with the increase of $\mathrm{H}_{2} \mathrm{O}_{2}$ concentration in the range of $0.007-15 \mathrm{mM}$ and a detection limit of $5 \mu \mathrm{M}$. The $\mathrm{H}_{2} \mathrm{O}_{2}$ sensor showed high selectivity for $\mathrm{H}_{2} \mathrm{O}_{2}$ detection, which could effectively resist the interference of ascorbic acid (AA), uric acid (UA), and citric acid (CA). Finally, the $\mathrm{H}_{2} \mathrm{O}_{2}$ sensor was used in the real fetal bovine serum to detect $\mathrm{H}_{2} \mathrm{O}_{2}$ and obtained satisfactory results with the recovery values ranging from 95.14 to $103.6 \%$.

\section{Introduction}

Magnetic nanoparticles have been popularly applied in anode material [1], degradation [2], electromagnetic wave absorption [3], separation [4], and catalysis [5]. Among these diverse magnetic nanomaterials reported before, $\mathrm{Fe}_{3} \mathrm{O}_{4}$ NPs have been studied extensively because of their excellent magnetism, biocompatibility, and especially, highly effective electrocatalytic activity. For example, Kingsley et al. fabricated $\mathrm{Fe}_{3} \mathrm{O}_{4}$ nanoparticle- (NP-) modified carbon paste electrode to detect ascorbic acid (AA) and folic acid (FA) at the same time, with the detection limits of $2.51 \times 10^{-7}$ and $2.01 \times 10^{-9} \mathrm{M}$, respectively [6]. $\mathrm{Qu}$ and coworkers established a novel hydrogen peroxide $\left(\mathrm{H}_{2} \mathrm{O}_{2}\right)$ sensor using $\mathrm{Fe}_{3} \mathrm{O}_{4}$ $\mathrm{NPs} /$ chitosan composite-modified electrode, which could electrocatalyze the reduction of $\mathrm{H}_{2} \mathrm{O}_{2}$ with a detection limit of $1.53 \times 10^{-6} \mathrm{M}$ [7]. However, $\mathrm{Fe}_{3} \mathrm{O}_{4} \mathrm{NPs}$ are unstable and prone to be aggregated and settled in aqueous solution because of the magnetic dipolar-dipolar attraction, resulting in the decrease of their catalytic activity [8]. To overcome this problem, considerable efforts have been devoted to introduce stabilizers on the surface of $\mathrm{Fe}_{3} \mathrm{O}_{4}$ NPs.

In recent years, core/shell structured magnetic nanocomposites have been proposed, with $\mathrm{Fe}_{3} \mathrm{O}_{4} \mathrm{NPs}$ as the core and inorganic materials or polymers as the shell. These specific core/shell $\mathrm{Fe}_{3} \mathrm{O}_{4}$ materials possess enhanced stability and compatibility with different charges, functions, or reactive moieties. Owing to the enlarged effective surface area and the synergetic interaction between core and shell, these nanocomposites usually combine the advantageous properties of both core and shell [9]. For example, Beitollahi and coworkers synthesized a carbon paste electrode modified with magnetic $\mathrm{Fe}_{3} \mathrm{O}_{4} @ \mathrm{SiO}_{2} / \mathrm{MWCNT}$ nanocomposite and found it exhibiting a very good resolution between the voltammetric peaks of hydrazine and phenol, which made it suitable for the detection of hydrazine in the presence of phenol in real samples [10]. Wang and coworkers showed that the $\mathrm{Fe}_{3} \mathrm{O}_{4} @ \mathrm{ZnO}$ nanoparticles (NPs) have excellent photocatalytic activity and it is convenient to reuse NPs in wastewater treatment owing to the magnetic $\mathrm{Fe}_{3} \mathrm{O}_{4}$ core [11]. 
Therefore, magnetic core/shell nanocomposites with multiple properties have been widely used.

Among these shell materials, carbon and gold are the most applied coating materials due to their excellent conductivity and biocompatibility $[12,13]$. In addition, on the surface of carbon shells, abundant amounts of hydroxyl $(-\mathrm{OH})$ and carboxyl $(-\mathrm{COOH})$ groups can effectively protect the $\mathrm{Fe}_{3} \mathrm{O}_{4}$ NPs from aggregation and facilitate further functional modification over the surface. Hence, the applicability of $\mathrm{Fe}_{3} \mathrm{O}_{4} @ \mathrm{C}$ has been extensively promoted. For example, Zhang and coworkers synthesized $\mathrm{Fe}_{3} \mathrm{O}_{4} @ \mathrm{C} \mathrm{NPs}$, which showed dramatic ability to remove methylene blue, with a maximum adsorption of $141.3 \mathrm{mg} \cdot \mathrm{g}^{-1}$ [14]. Zhang and coworkers fabricated another $\mathrm{Fe}_{3} \mathrm{O}_{4} @ \mathrm{C}$ NPs immobilized upon the GCE which was modified with molecular imprinted $\mathrm{TiO}_{2}$ velamen. It was then made into the uric acid sensor, which delivered a linear range of $0.3-34 \mu \mathrm{M}$ with a detection limit of $0.02 \mu \mathrm{M}$ [15]. Meanwhile, functionalized $\mathrm{Fe}_{3} \mathrm{O}_{4} @ \mathrm{Au}$ NPs have also been applied in As (III) [16] and dopamine [17] sensors, respectively.

In this work, $\mathrm{Fe}_{3} \mathrm{O}_{4} @ \mathrm{C}$ core/shell nanocomposite was synthesized by a facile solvothermal method from ferrocene as the raw material. It was not only easily separated by an external magnetic field but also possessed excellent dispersion in water. To further enhance the conductivity and catalytic activity, Au NPs were adsorbed on the surface of the obtained $\mathrm{Fe}_{3} \mathrm{O}_{4} @ \mathrm{C}$ nanospheres by electrostatic attraction. The synthesized $\mathrm{Fe}_{3} \mathrm{O}_{4} @ \mathrm{C} / \mathrm{Au}$ NPs were first used to fabricate a nonenzymatic $\mathrm{H}_{2} \mathrm{O}_{2}$ sensor and showed high electrochemical sensitivity.

\section{Materials and Methods}

2.1. Materials. Ferrocene, acetone, sodium citrate, absolute ethanol, sodium chloride $(\mathrm{NaCl})$, and Tris base were purchased from Shanghai Lingfeng Chemical Reagent (China). Poly(diallyldimethylammonium chloride) (PDDA, 20 wt. \%) was purchased from Aldrich. Chloroauric acid hydrated $\left(\mathrm{HAuCl}_{4} \cdot 4 \mathrm{H}_{2} \mathrm{O}\right)$ and sodium citrate were purchased from Nanjing Chemical Reagent (China). $\mathrm{H}_{2} \mathrm{O}_{2}$ (30\%) was obtained from Sinopharm Chemical Reagent. Phosphate buffer saline (PBS, $0.1 \mathrm{M}$ ) was prepared by mixing the stock solutions of $\mathrm{KH}_{2} \mathrm{PO}_{4}$ and $\mathrm{K}_{2} \mathrm{HPO}_{4}$ and was adjusted to the appropriate $\mathrm{pH}$ value. Uric acid (UA), AA, and citric acid (CA) were all purchased from Sigma. Nafion (Nf) was obtained from DuPont as $5 \mathrm{wt} \%$ solution and was used as 0.5 $w t \%$ solution after dilution with water. Other reagents were of analytical grade and used without further purification. Double distilled water (DDW) was used throughout the experiments.

2.2. Characterization. The structures and morphologies of the $\mathrm{Fe}_{3} \mathrm{O}_{4} @ \mathrm{C}$ and $\mathrm{Fe}_{3} \mathrm{O}_{4} @ \mathrm{C} / \mathrm{AuNPs}$ were characterized by transmission electron microscopy (TEM, JEOL JEM-200CX) and field emission scanning electron microscopy (FESEM, Hitachi S4800). Fourier transform infrared (FT-IR) spectra of $\mathrm{KBr}$ powder-pressed pellets were recorded on a Bruker model VECTOR 22 Fourier transform spectrometer. Elemental composition and chemical valence analyses were performed on X-ray diffraction (XRD, Rigaku SmartLab) and X-ray photoelectron spectroscopy (XPS, Thermo Scientific K-Alpha), respectively.

Cyclic voltammetry (CV), differential pulse voltammetry (DPV), and electrochemical impedance spectroscopy (EIS) were performed using a CHI 660D electrochemical workstation (Shanghai Chenhua Instruments, China). A threecompartment electrochemical cell contained a saturated calomel reference electrode (SCE), a platinum wire auxiliary electrode, and a modified ITO working electrode with a $3 \mathrm{~mm}$ diameter controlled area. The determination of $\mathrm{H}_{2} \mathrm{O}_{2}$ was conducted in 0.1 M PBS, and the sensor responses were measured under deductions for background currents from the total ones.

\subsection{Preparation of $\mathrm{Fe}_{3} \mathrm{O}_{4} @ C / A u N P$ Magnetic Nanocomposite.} Core/shell structured $\mathrm{Fe}_{3} \mathrm{O}_{4} @ \mathrm{C}$ magnetic nanocomposite was prepared by Wang's method [18]. First, $0.3 \mathrm{~g}$ of ferrocene was dissolved in $30 \mathrm{~mL}$ of acetone under ultrasonication at room temperature for $30 \mathrm{~min}$. Then, $1 \mathrm{~mL}$ of $\mathrm{H}_{2} \mathrm{O}_{2}$ was added dropwise into the above ferrocene solution. After reacting for $15 \mathrm{~min}$ under stirring, the resulting solution was transferred into a Teflon-lined stainless-steel autoclave with a capacity of $50 \mathrm{~mL}$ and heated at $210^{\circ} \mathrm{C}$ for $24 \mathrm{~h}$. After cooling to room temperature, the product was magnetically separated, washed several times with absolute ethanol, and finally dried under vacuum at $50^{\circ} \mathrm{C}$ for $5 \mathrm{~h}$.

$\mathrm{Au}$ colloid solution was prepared by adding $5 \mathrm{~mL}$ of $1 \%$ (wt. \%) sodium citrate into $200 \mathrm{~mL}$ of $0.01 \%$ (wt. \%) $\mathrm{HAuCl}_{4}$, which had been heated to boil beforehand. Heating was stopped by the change of solution color from light blue to violet-red and stirring was continued for $15 \mathrm{~min}$. After cooling to room temperature, $\mathrm{Au}$ colloid solution was preserved in a refrigerator at $4^{\circ} \mathrm{C}$. Generally, an electrostatic attraction method was used for the immobilization of AuNPs onto the surface of the $\mathrm{Fe}_{3} \mathrm{O}_{4} @ \mathrm{C}$ core/shell nanocomposite. $50 \mathrm{mg}$ of $\mathrm{Fe}_{3} \mathrm{O}_{4} @ \mathrm{C}$ nanocomposite was dispersed into $30 \mathrm{~mL}$ of $0.2 \%$ PDDA that contained $20 \mathrm{mM}$ Tris base and $20 \mathrm{mM} \mathrm{NaCl}$, and the mixture was stirred for $20 \mathrm{~min}$. The product was collected with the help of a magnet and rinsed with DDW six times to remove the residual PDDA. The positively charged $\mathrm{Fe}_{3} \mathrm{O}_{4} @ \mathrm{C}$ nanocomposite was dispersed in $100 \mathrm{~mL}$ of Au colloid solution and stirred for $8 \mathrm{~h}$. The suspension was separated with the help of a magnet. After rinsed with water and ethanol three times successively, the $\mathrm{Fe}_{3} \mathrm{O}_{4} @ \mathrm{C} / \mathrm{AuNP}$ nanocomposite was dried under vacuum at $50^{\circ} \mathrm{C}$ for $6 \mathrm{~h}$.

\subsection{Fabrication of $\mathrm{Fe}_{3} \mathrm{O}_{4} @ \mathrm{C} / \mathrm{AuNP}$-Modified ITO Magnetism} Electrode. Before modification, the ITO chips were cleaned with acetone, ethanol, and water, respectively, and then dried under a stream of nitrogen. The active electrode area was confined by bounding a circular opened $3 \mathrm{M}$ polyvinyl chloride (PVC) film on the ITO surface, with a $3 \mathrm{~mm}$ diameter on the middle of the electrode. On the other side of the ITO, a piece of $8 \mathrm{~mm}$ diameter and $5 \mathrm{~mm}$ height permanent magnet was adhered by silica rubber adhesive [19]. 
Then, $10 \mu \mathrm{L}$ of $1 \mathrm{mg} \cdot \mathrm{mL}^{-1} \mathrm{Fe}_{3} \mathrm{O}_{4} @ \mathrm{C} / \mathrm{AuNP}$ nanocomposite dispersion (in $5 \mathrm{~mL} 0.5 \% \mathrm{Nf}$ ) was dropped onto the surface of the ITO magnetism electrode and dried at room temperature, which was designated as $\mathrm{Fe}_{3} \mathrm{O}_{4} @ \mathrm{C} / \mathrm{AuNPs} / \mathrm{Nf} /$ ITO. When the sensor was not in use, it was stored at $4^{\circ} \mathrm{C}$ in a refrigerator.

\section{Results and Discussion}

3.1. Structure and Composition Characterization of Samples. The structure and morphology of the nanocomposites were investigated by TEM and FESEM. In Figure 1(a), $\mathrm{Fe}_{3} \mathrm{O}_{4} @ \mathrm{C}$ with obvious core/shell structures were successfully synthesized. The presence of carbon shells prevented agglomeration of the $\mathrm{Fe}_{3} \mathrm{O}_{4}$ NPs and improved the dispersity of the $\mathrm{Fe}_{3} \mathrm{O}_{4} @ \mathrm{C}$, with an average diameter of approximately $125 \mathrm{~nm}$. As vividly shown in Figure 1(b), the SEM image of $\mathrm{Fe}_{3} \mathrm{O}_{4} @ \mathrm{C}$ displays a distinct margin without agglomeration. Figure 1(c) shows the TEM image of $\mathrm{Fe}_{3} \mathrm{O}_{4} @ \mathrm{C} / \mathrm{AuNPs}$ with a diameter of $141 \mathrm{~nm}$. It is clear that there are numerous dark spots embedded in the outer shells, indicating that AuNPs were successfully immobilized on the surface of the $\mathrm{Fe}_{3} \mathrm{O}_{4} @$ $\mathrm{C}$ nanospheres, with an average diameter of approximately $15 \mathrm{~nm}$. Figure $1(\mathrm{~d})$ shows the SEM image of the rather rough surface of $\mathrm{Fe}_{3} \mathrm{O}_{4} @ \mathrm{C} / \mathrm{AuNP}$ with a raspberry-shaped morphology compared to that of $\mathrm{Fe}_{3} \mathrm{O}_{4} @ \mathrm{C}$. Moreover, some of them are overlapped or amalgamated due to external immobilization of AuNPs, which amplify the superficial roughness. And the dispersity of the $\mathrm{Fe}_{3} \mathrm{O}_{4} @ \mathrm{C}$ nanocomposites is weakened by electrostatic attraction between AuNPs and $\mathrm{Fe}_{3} \mathrm{O}_{4} @ \mathrm{C}$ as well. The inset in Figure 1(d) shows the elemental composition of $\mathrm{Fe}_{3} \mathrm{O}_{4} @ \mathrm{C} / \mathrm{AuNPs}$ and the $\mathrm{Au}$ atom mass concentration is $3.57 \%$.

FT-IR was used to characterize the chemical structure of the samples. Figure 2(a) shows the FT-IR spectra of $\mathrm{Fe}_{3} \mathrm{O}_{4}$ (curve a), $\mathrm{Fe}_{3} \mathrm{O}_{4} @ \mathrm{C}$ (curve b), and $\mathrm{Fe}_{3} \mathrm{O}_{4} @ \mathrm{C} / \mathrm{AuNPs}$ (curve c). The characteristic peak appears at $590 \mathrm{~cm}^{-1}$ which is related to the $\mathrm{Fe}-\mathrm{O}$ stretching vibration [20]. Compared with curve $a$, there is a new strong band in curve $b$ at around $3446 \mathrm{~cm}^{-1}$, indicating the presence of $-\mathrm{OH}$ in the carbon shell. These phenomena further proved that the carbon shell is successfully coated on the surface of the $\mathrm{Fe}_{3} \mathrm{O}_{4}$ nanosphere. The peak located at $1399 \mathrm{~cm}^{-1}$ is attributed to the COO- symmetric vibration [21]. Actually, the carboxyl group-functionalized $\mathrm{Fe}_{3} \mathrm{O}_{4} @ \mathrm{C}$ nanospheres are negatively charged. This is the reason why we use PDDA to make the surface of carbon shell positively charged for the assembly of negatively charged AuNPs via electrostatic interaction. Curve $c$ shows the FT-IR spectrum of $\mathrm{Fe}_{3} \mathrm{O}_{4} @ \mathrm{C} / \mathrm{AuNPs}$. Because AuNPs do not have absorption in the IR region, the characteristic peak of $\mathrm{Fe}_{3} \mathrm{O}_{4} @ \mathrm{C} / \mathrm{AuNPs}$ is almost the same as that of $\mathrm{Fe}_{3} \mathrm{O}_{4} @ \mathrm{C}$.

To characterize the crystal information of the prepared $\mathrm{Fe}_{3} \mathrm{O}_{4} @ \mathrm{C} / \mathrm{AuNP}$ further, the XRD has been performed. As shown in Figure 2(b), the diffraction peaks appeared at $30^{\circ}$, $35.5^{\circ}, 43^{\circ}, 57^{\circ}$, and $62^{\circ}$ are originated from $\mathrm{Fe}_{3} \mathrm{O}_{4}$, corresponding to (220), (311), (400), (511), and (440) crystal planes [22]. In addition to those peaks, another peak at $38.2^{\circ}$ is in good accordance with (111) plane of AuNPs. It is difficult to discriminate $\mathrm{Fe}_{3} \mathrm{O}_{4}$ phases from $\gamma-\mathrm{Fe}_{2} \mathrm{O}_{3}$ by only using XRD patterns due to the similarity of patterns, and XPS is conducted to characterize the electronic structures of Fe element in the nanocomposite, which is known to be sensitive to $\mathrm{Fe}^{2+}$ and $\mathrm{Fe}^{3+}$ cations. Figure 2(c) presents two peaks at the binding energies of 724.4 and $711.4 \mathrm{eV}$, which correspond to the maximum intensity of $\mathrm{Fe} 2 \mathrm{p} 1 / 2$ and $\mathrm{Fe}$ $2 \mathrm{p} 3 / 2$, illustrating the coexistence of $\mathrm{Fe}^{2+}$ and $\mathrm{Fe}^{3+}$ cations in $\mathrm{Fe}_{3} \mathrm{O}_{4} @ \mathrm{C} / \mathrm{AuNPs}$ [23]. Peaks of $\mathrm{Au}$ are also shown in Figure 2(d), corresponding to $\mathrm{Au} 4 \mathrm{f} 2 / 7$ and $\mathrm{Au} 4 \mathrm{f} 2 / 5$, respectively. From the above characterization results, the welldefined core/shell structured $\mathrm{Fe}_{3} \mathrm{O}_{4} @ \mathrm{C} / \mathrm{AuNPs}$ is confirmed to be constructed.

3.2. Characterization of Nanocomposite-Modified ITO Electrodes. The influence of potential scan rate $(v)$ on the response of the $\mathrm{Fe}_{3} \mathrm{O}_{4} @ \mathrm{C} / \mathrm{AuNP}$-modified ITO electrode in PBS was studied, as shown in Figure 3(a). The reduction and oxidation peak currents $\left(\mathrm{i}_{\mathrm{pa}}\right.$ and $\mathrm{i}_{\mathrm{pc}}$ ) increased linearly with the square root of scan rate $\left(v^{1 / 2}\right)$ accelerating from 40 to $300 \mathrm{mV} \cdot \mathrm{s}^{-1}$, indicating a surface-controlled electrochemical process.

As shown in Figure 3(b), we also recorded the CVs of various modified electrodes towards $0.1 \mathrm{mM} \mathrm{H}_{2} \mathrm{O}_{2}$ in $0.1 \mathrm{M}$ $\mathrm{pH} 7.4 \mathrm{PBS}$ at a scan rate of $100 \mathrm{mV} \cdot \mathrm{s}^{-1}$. At the bare ITO, almost no peak of $\mathrm{H}_{2} \mathrm{O}_{2}$ is observed (curve a), except for a slight reduction peak. After the electrode was modified with $\mathrm{Fe}_{3} \mathrm{O}_{4} @ \mathrm{C}$ nanocomposites, a small increase in $\mathrm{i}_{\text {pa }}$ was observed (curve b), indicating the electrocatalytic reduction activity toward $\mathrm{H}_{2} \mathrm{O}_{2}$ possessed by $\mathrm{Fe}_{3} \mathrm{O}_{4} @ \mathrm{C}$ nanocomposites. The reduction peak potential was around $-0.35 \mathrm{~V}$, similar to another reported nonenzymatic $\mathrm{H}_{2} \mathrm{O}_{2}$ sensor [24] and the $\mathrm{i}_{\text {pa }}$ was 1.7 times higher compared with that in curve a. When the $\mathrm{Fe}_{3} \mathrm{O}_{4} @ \mathrm{C} / \mathrm{AuNPs}$ were assembled on the electrode, the peak current significantly increased (curve c) and the $i_{p a}$ is 2.4 times that of curve b, demonstrating that the AuNPs significantly improve the catalytic activity of $\mathrm{Fe}_{3} \mathrm{O}_{4} @ \mathrm{C}$ nanocomposites.

The electron transfer rate and the interfacial resistance, as shown in Figures 4(a) and 4(b), respectively, can reflect the electrochemical properties. In Figure 4(a), obvious oxidation and reduction peaks were observed on both $\mathrm{Fe}_{3} \mathrm{O}_{4} @ \mathrm{C}$ - and $\mathrm{Fe}_{3} \mathrm{O}_{4} @ \mathrm{C} / \mathrm{AuNP}$-modified electrodes, belonging to different valences of Fe element. An increased peak current was found after surface modification with AuNPs, indicating that noble metals could promote electron transfer on the electrode. In addition, the electroactive surface area (ESA) was calculated to be $1.628 \mathrm{~cm}^{2}$ by Randles-Sevcik equation, which is nearly 23 times the geometric area. It means that the modification of $\mathrm{Fe}_{3} \mathrm{O}_{4} @ \mathrm{C} / \mathrm{AuNPs}$ increased the roughness of the electrode surface greatly, which could facilitate the absorption, transmission, and catalysis of $\mathrm{H}_{2} \mathrm{O}_{2}$.

Similar results were also confirmed by EIS measurements, as shown in Figure 4(b). The diameter of the Nyquist curve revealed charge transfer resistance of the electrode $\left(\mathrm{R}_{\mathrm{ct}}\right)$, and a larger diameter means a greater resistance. Curve 


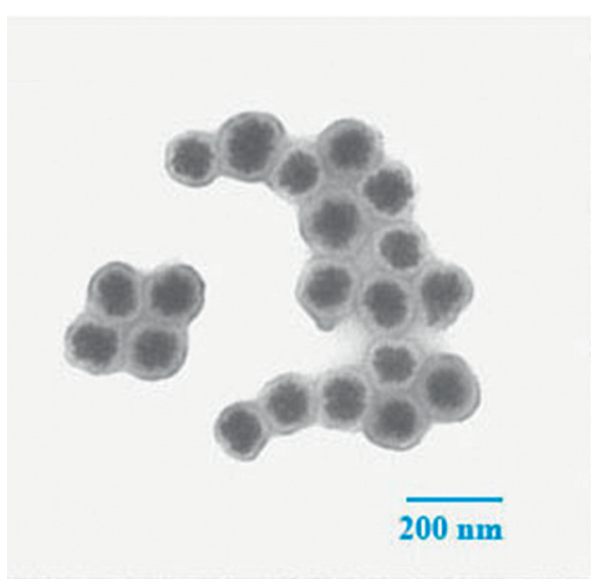

(a)

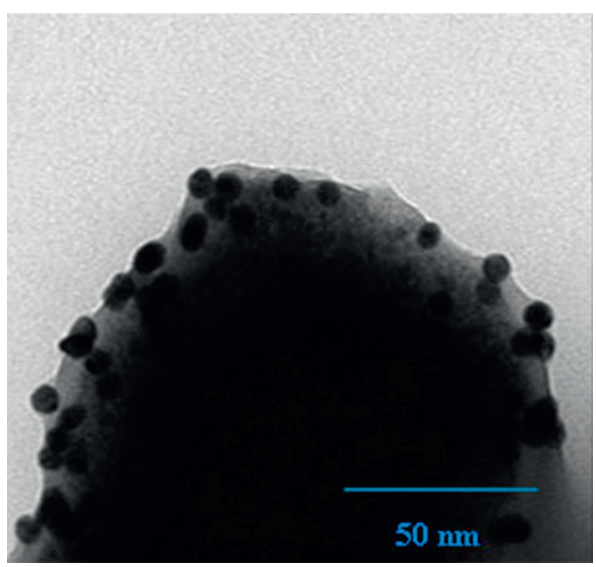

(c)

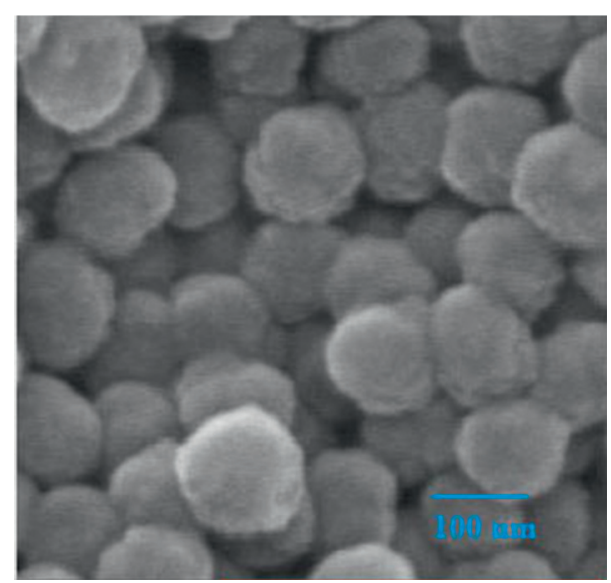

(b)

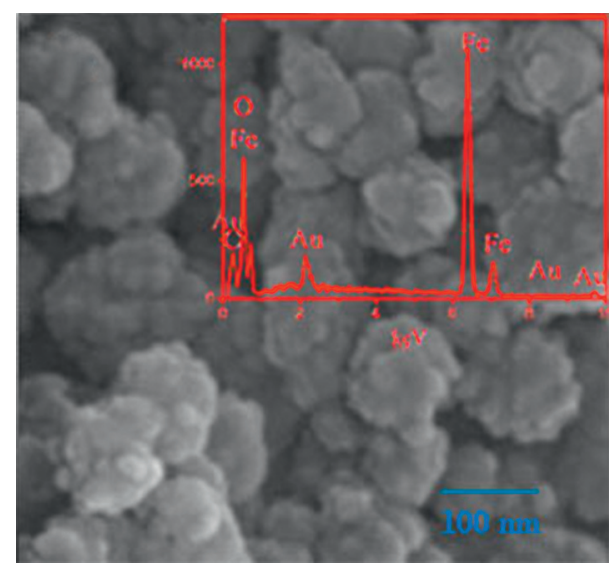

(d)

Figure 1: (a, c) TEM and (b, d) FESEM images of $\mathrm{Fe}_{3} \mathrm{O}_{4} @ \mathrm{C}$ and $\mathrm{Fe}_{3} \mathrm{O}_{4} @ \mathrm{C} /$ AuNPs. The inset shows the elemental composition of $\mathrm{Fe}_{3} \mathrm{O}_{4} @ \mathrm{C} / \mathrm{AuNPs}$.

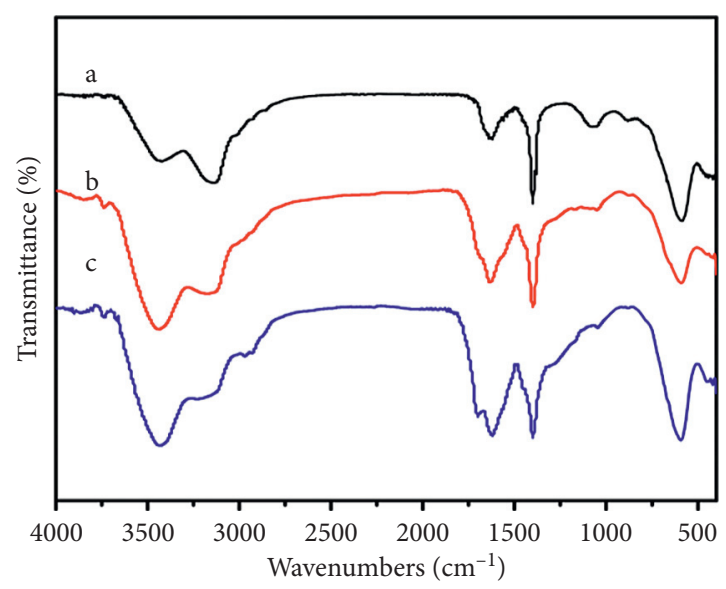

(a)

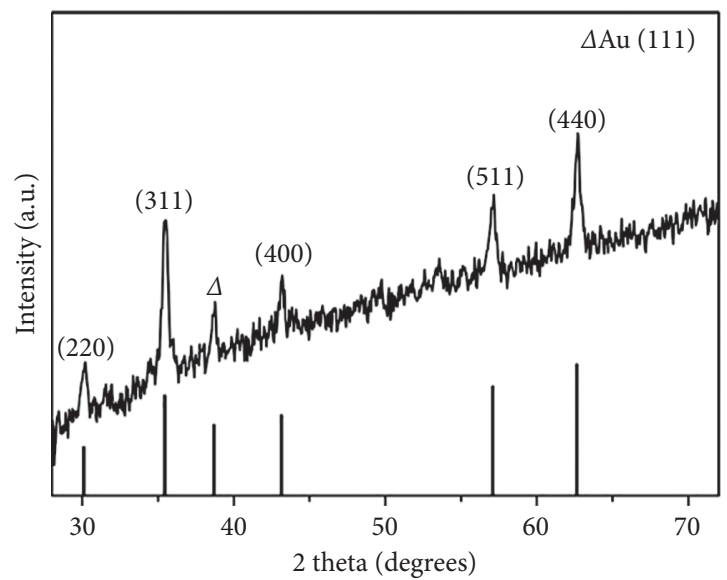

(b)

FIgUre 2: Continued. 


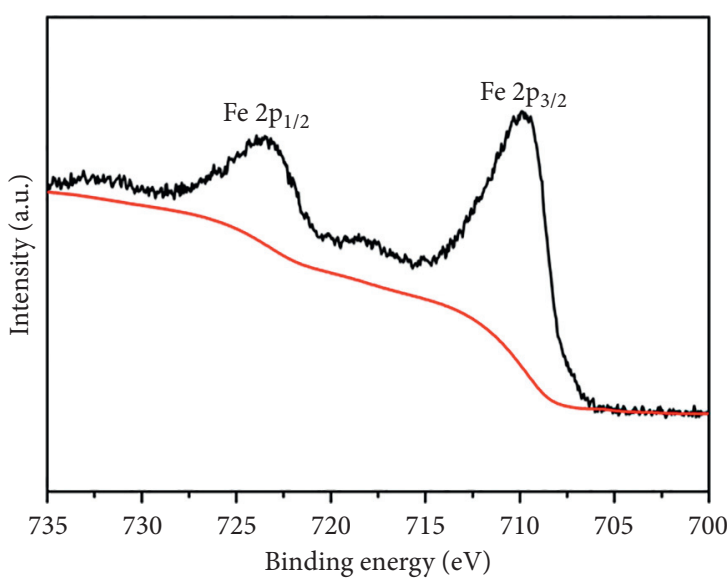

(c)

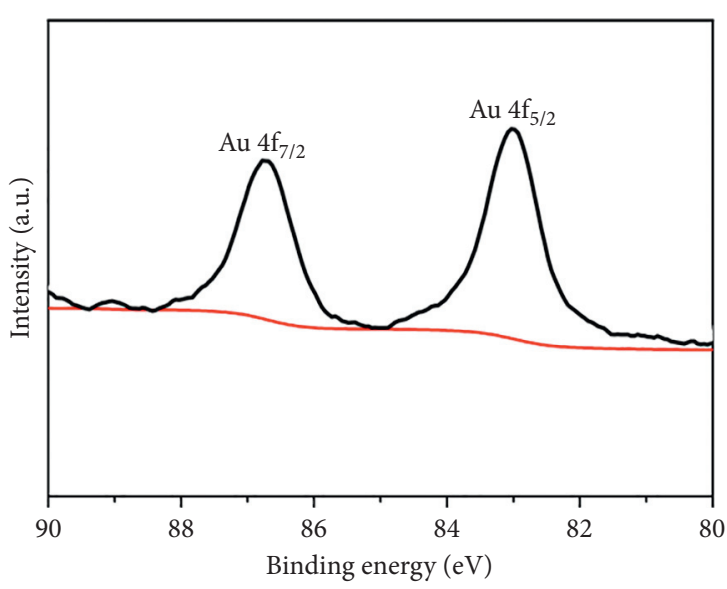

(d)

Figure 2: (a) FT-IR spectra of the $\mathrm{Fe}_{3} \mathrm{O}_{4}$ (curve a), $\mathrm{Fe}_{3} \mathrm{O}_{4} @ \mathrm{C}$ (curve b), and $\mathrm{Fe}_{3} \mathrm{O}_{4} @ \mathrm{C} /$ AuNPs (curve c), respectively, (b) XRD spectra of the $\mathrm{Fe}_{3} \mathrm{O}_{4} @ \mathrm{C} / \mathrm{AuNPs}$. XPS spectra of (c) Fe 2p and (d) $\mathrm{Au} 4 \mathrm{f}$ from $\mathrm{Fe}_{3} \mathrm{O}_{4} @ \mathrm{C} / \mathrm{AuNPs}$.

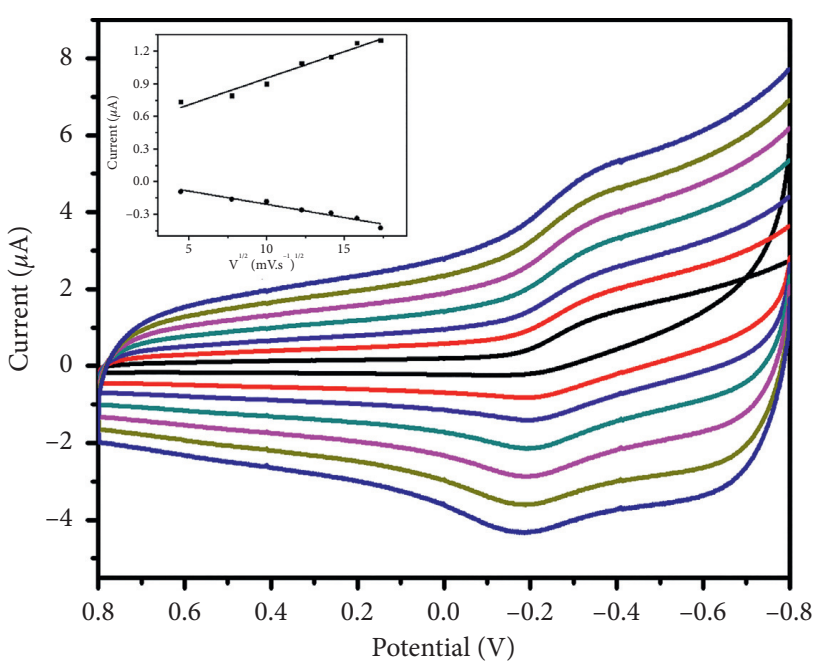

(a)

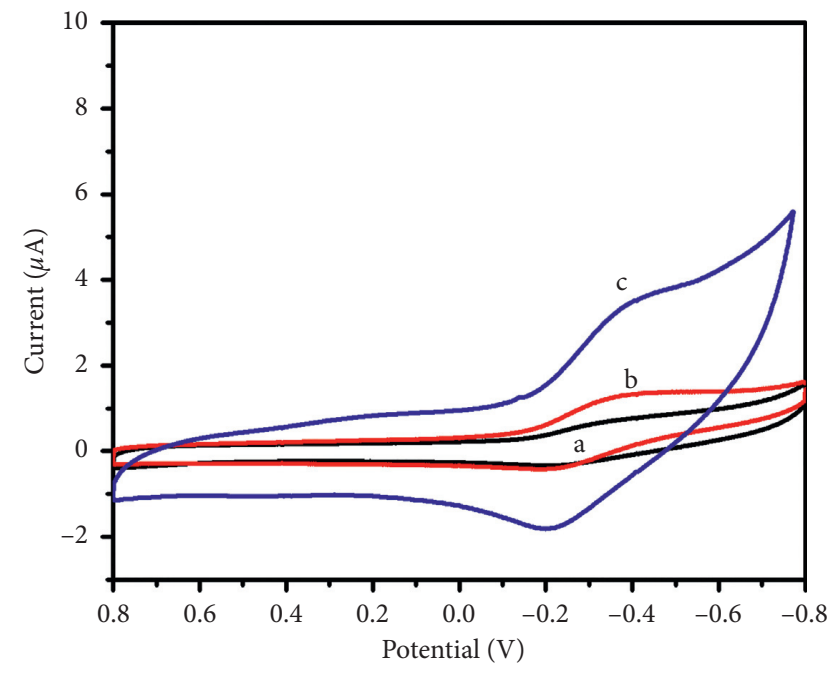

(b)

Figure 3: (a) CVs of $\mathrm{Fe}_{3} \mathrm{O}_{4} @ \mathrm{C} / \mathrm{AuNP} / \mathrm{ITO}$ at the scan rates of 40, 60, 100, 150, 200, 250, and $300 \mathrm{mV} \cdot \mathrm{s}^{-1}$ (from internal to external) in $0.1 \mathrm{M}$ $\mathrm{pH}$ 7.4 PBS containing $0.1 \mathrm{mM} \mathrm{H}_{2} \mathrm{O}_{2}$, respectively. The inset shows the linear plots of the peak current vs. $v^{1 / 2}$; (b) CVs of different modified electrodes: bare ITO (curve a), $\mathrm{Fe}_{3} \mathrm{O}_{4} @ \mathrm{C} / \mathrm{ITO}$ (curve b), and $\mathrm{Fe}_{3} \mathrm{O}_{4} @ \mathrm{C} / \mathrm{AuNP} / \mathrm{ITO}$ (curve c) in $0.1 \mathrm{M} \mathrm{pH} 7.4 \mathrm{PBS}_{\text {containing } 0.1 \text { mM H}} \mathrm{O}_{2}$ at a scan rate of $100 \mathrm{mV} \cdot \mathrm{s}^{-1}$.

a presented a smaller $\mathrm{R}_{\mathrm{ct}}$ value at $\mathrm{Fe}_{3} \mathrm{O}_{4} @ \mathrm{C} / \mathrm{AuNP}$-modified ITO, verifying AuNPs could enhance charge transfer significantly, compared with that in curve b.

3.3. Optimization of Experimental Parameters. The variations of oxidation-reduction potential of $\mathrm{H}_{2} \mathrm{O}_{2}$ in different $\mathrm{pH}$ values indicate diverse oxidation ability of $\mathrm{H}_{2} \mathrm{O}_{2}$, resulting in different sensitivities of sensors under different $\mathrm{pH}$ circumstances. The effect of solution $\mathrm{pH}$ on the electrocatalytic reduction of $\mathrm{H}_{2} \mathrm{O}_{2}$ was investigated. Figure 5(a) shows the linear plots of the reduction peak current versus the concentration of $\mathrm{H}_{2} \mathrm{O}_{2}$ from 0.1 to $1 \mathrm{mM}$ over the $\mathrm{pH}$ range from 6 to 9 . The electrocatalytic activity and sensitivity were much higher at the $\mathrm{pH}$ value of 7-8 and lower at 6 and 8. The possible reason was that $\mathrm{Fe}_{3} \mathrm{O}_{4}$ core was expected to dissolve in acidic circumstances and the catalytic activity faded. Meanwhile, $\mathrm{H}_{2} \mathrm{O}_{2}$ is prone to lose oxidizing ability with solution alkalinity increasing. Therefore, a nearly neutral condition is suitable for $\mathrm{H}_{2} \mathrm{O}_{2}$ detection and the PBS with physiologic $\mathrm{pH}$ value of human being which is about 7.4 was chosen as the supporting electrolyte.

Figure 5(b) exhibits reduction peak current versus different modification amounts of $\mathrm{Fe}_{3} \mathrm{O}_{4} @ \mathrm{C} / \mathrm{AuNPs}$. The response current towards $1 \mathrm{mM} \mathrm{H}_{2} \mathrm{O}_{2}$ rose along with the modification amount of $\mathrm{Fe}_{3} \mathrm{O}_{4} @ \mathrm{C} / \mathrm{AuNP}$ increasing from 0.6 to $1 \mathrm{mg} \cdot \mathrm{mL}^{-1}$ and reached a plateau when the modification amount exceeded $1 \mathrm{mg} \mathrm{mL}^{-1}$. The response speed was 


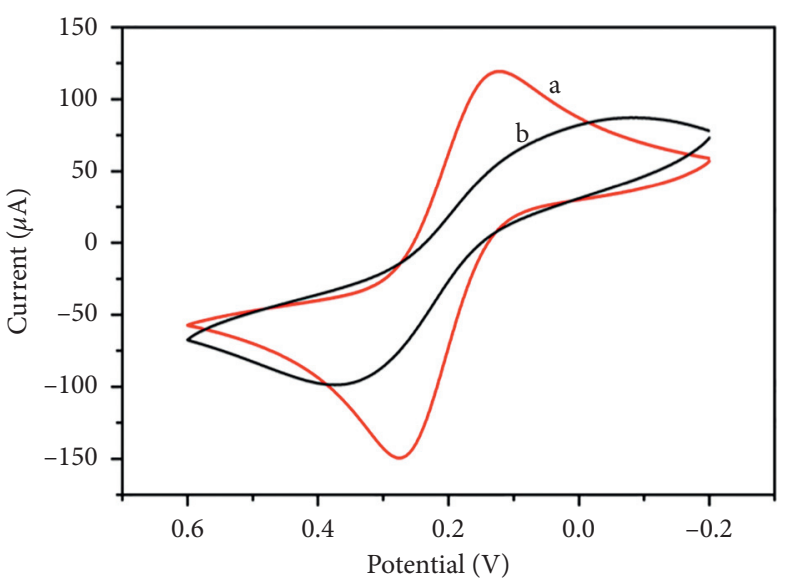

(a)

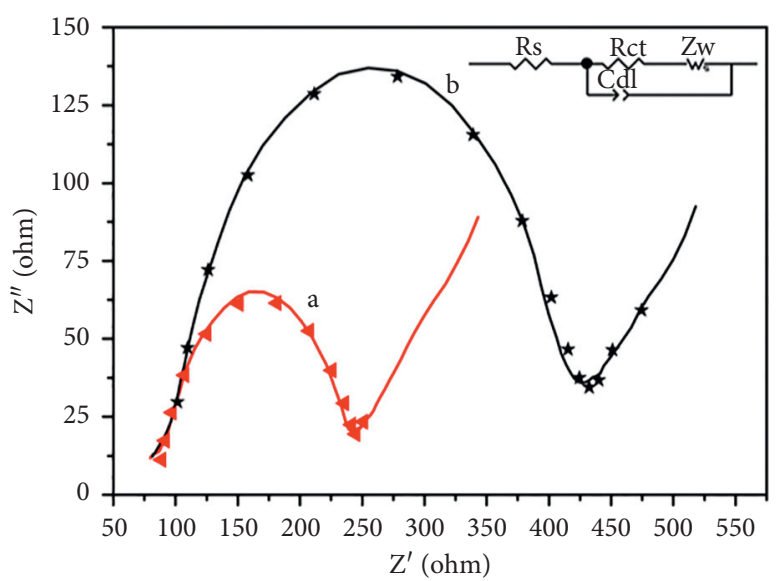

(b)

Figure 4: (a) CV and (b) EIS curves of $\mathrm{Fe}_{3} \mathrm{O}_{4} @ \mathrm{C} / \mathrm{AuNPs} / \mathrm{ITO}$ (curve a) and $\mathrm{Fe}_{3} \mathrm{O}_{4} @ \mathrm{C} / \mathrm{ITO}$ (curve b) in 0.1 M of pH 7.4 PBS containing 0.1 M $\mathrm{KCl}$ and $5 \mathrm{mM}[\mathrm{Fe}(\mathrm{CN}) 6]^{3-/ 4-}$.

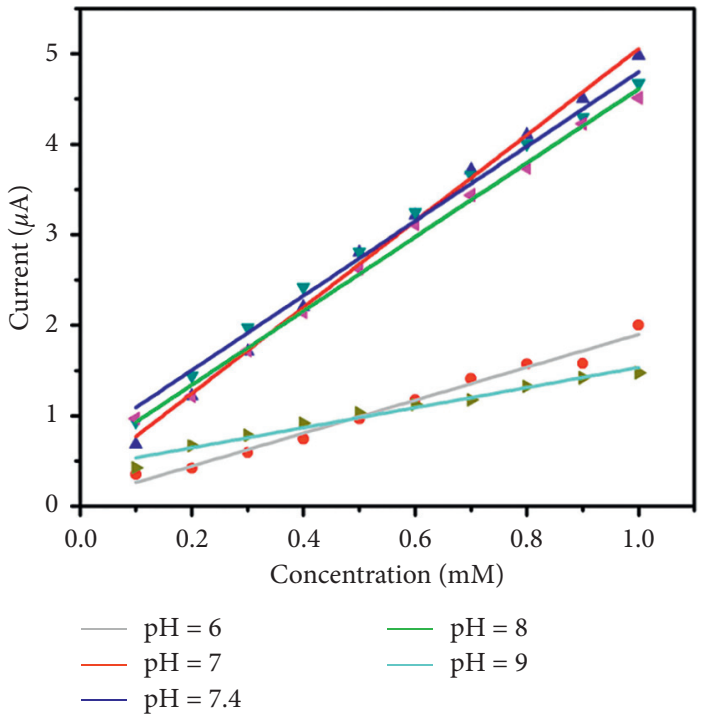

(a)

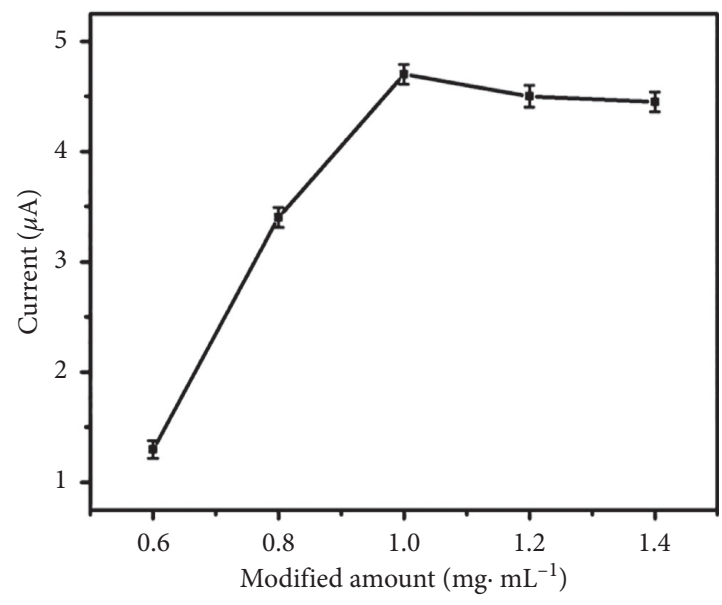

(b)

Figure 5: (a) Linear plots of the reduction peak current versus the concentration of $\mathrm{H}_{2} \mathrm{O}_{2}$ from 0.1 to $1 \mathrm{mM}$ over the pH range from 6 to 9 at $\mathrm{Fe}_{3} \mathrm{O}_{4} @ \mathrm{C} / \mathrm{AuNP} / \mathrm{ITO}$ electrode; (b) dependence of reduction peak current of $1 \mathrm{mM} \mathrm{H}_{2} \mathrm{O}_{2}$ in $0.1 \mathrm{M}$ pH $7.4 \mathrm{PBS}$ upon the modification amount of $\mathrm{Fe}_{3} \mathrm{O}_{4} @ \mathrm{C} /$ AuNPs.

supposed to be delayed by thickening modification, which brought hidden troubles of its falling off from the electrode surface. It may lead to a decreased stability of the modified electrode and the smaller response current. In this way, $1 \mathrm{mg} \cdot \mathrm{mL}^{-1}$ of $\mathrm{Fe}_{3} \mathrm{O}_{4} @ \mathrm{C} / \mathrm{AuNPs}$ was regarded to be the optimal amount of modification for $\mathrm{H}_{2} \mathrm{O}_{2}$ detection.

3.4. Amperometric Response of $\mathrm{H}_{2} \mathrm{O}_{2}$ Sensor. Figure 6 displays $\mathrm{CVs}$ in the presence of $\mathrm{H}_{2} \mathrm{O}_{2}$ at different concentrations under the optimum conditions. The response current shows a good linear relationship with the increase of $\mathrm{H}_{2} \mathrm{O}_{2}$ concentration in the range of $0.007-15 \mathrm{mM}$. The linear regression equations is $\Delta \mathrm{i}_{\mathrm{p}}(\mu \mathrm{A})=0.10+2.01 c\left(\mathrm{H}_{2} \mathrm{O}_{2}\right)(\mathrm{mM})\left(R^{2}=0.9988\right)$. The detection limit was estimated at $5 \mu \mathrm{M}$, and the theoretical sensitivity of this sensor was calculated to be $28.71 \mu \mathrm{A} \mathrm{mM}^{-1} \mathrm{~cm}^{-2}$. The response current became saturated when the concentration of $\mathrm{H}_{2} \mathrm{O}_{2}$ exceeded $15 \mathrm{mM}$. Quantitative detection of $\mathrm{H}_{2} \mathrm{O}_{2}$ concentration can be realized by the calculation with the linear equation. Furthermore, the performances including electrode modification, linear range, and detection limit of the $\mathrm{Fe}_{3} \mathrm{O}_{4} @ \mathrm{C} /$ AuNPs/ITO were compared with those of other $\mathrm{H}_{2} \mathrm{O}_{2}$ sensors, which are listed in Table 1. It was shown that the proposed $\mathrm{H}_{2} \mathrm{O}_{2}$ sensor in this work exhibited a wider linear range and a 


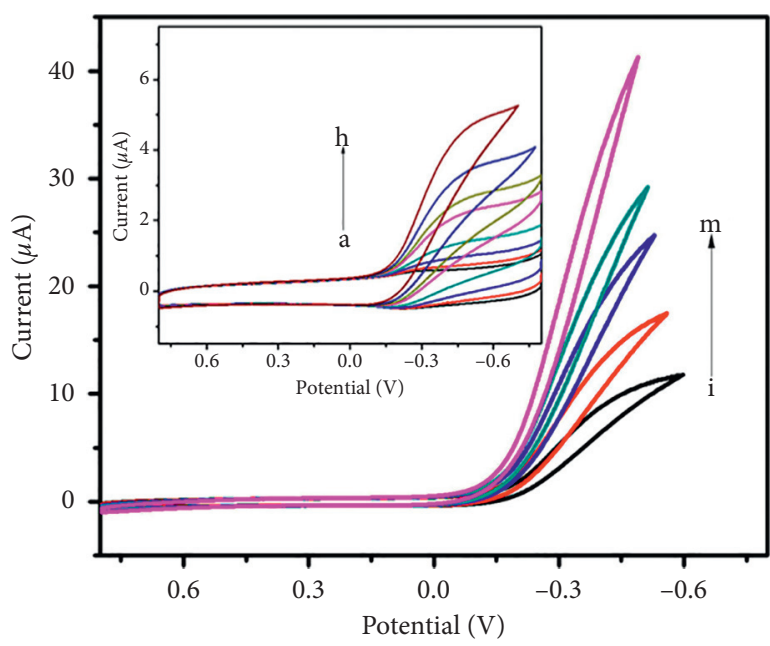

(a)

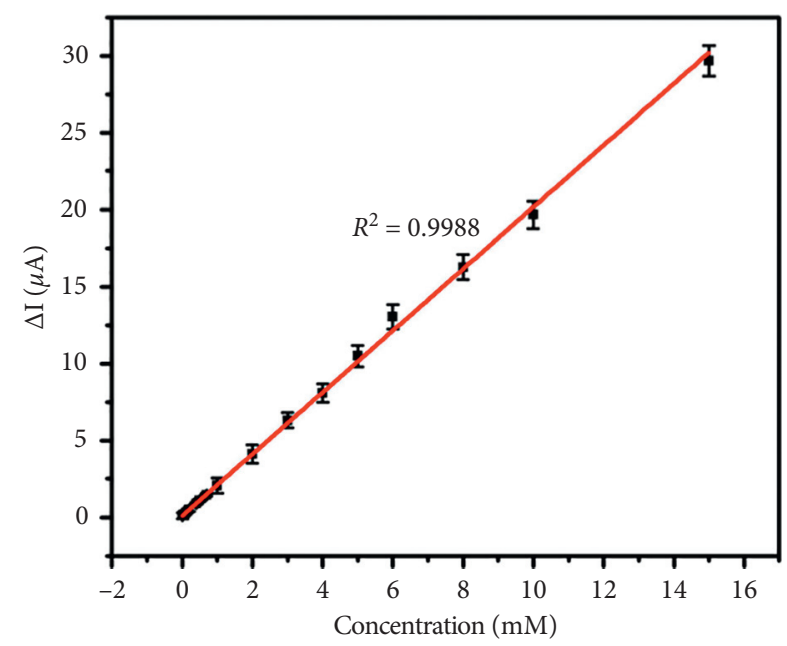

(b)

Figure 6: (a) CVs of $\mathrm{Fe}_{3} \mathrm{O}_{4} @ \mathrm{C} / \mathrm{AuNP}$ /ITO recorded in 0.1 M pH 7.4 PBS containing 0.007-15 $\mathrm{mM}$ of $\mathrm{H}_{2} \mathrm{O}_{2}$ (curves a to m, at a scan rate of $100 \mathrm{mV} \cdot \mathrm{s}^{-1}$. The inset shows the CVs corresponding to the $\mathrm{H}_{2} \mathrm{O}_{2}$ concentration in the range of $0.007-1 \mathrm{mM}$ (from a to h); (b) the calibration plot of the reduction peak current vs. the $\mathrm{H}_{2} \mathrm{O}_{2}$ concentration.

TABLE 1: The performance comparison of different nonenzymatic $\mathrm{H}_{2} \mathrm{O}_{2}$ sensors.

\begin{tabular}{lccc}
\hline Electrode modification & Linear range $(\mathrm{mM})$ & Detection limit $(\mu \mathrm{M})$ & Ref. \\
\hline $\mathrm{Co}_{3} \mathrm{O}_{4} / \mathrm{MWCNTs}$ & $0.02-0.43$ & 2.46 & {$[25]$} \\
$\mathrm{PtAu}$ & $0.05-1.15$ & 2.1 & {$[26]$} \\
$\mathrm{Pd} / \mathrm{CNT}$ & $0.008-9.5$ & 0.7 & {$[27]$} \\
$\mathrm{AgCo} / \mathrm{MWCNTs}$ & $0.05-10$ & 10 & {$[29]$} \\
$\mathrm{NPG} @ \mathrm{Ni}$ & $0.02-9.74$ & 3.1 & {$[30]$} \\
$\mathrm{Se} / \mathrm{PtNPs}$ & $0.01-1.5$ & 9.1 & {$[31]$} \\
$\mathrm{Ag} / \mathrm{NaX}$ & $0.02-11.76$ & 29.2 & {$[32]$} \\
$\mathrm{Ag} \mathrm{NW}$ array & $0.1-3.1$ & 27 & {$[33]$} \\
$\mathrm{AgNPs}$ & $0.05-6.5$ & 32.6 & $5]$ \\
$\mathrm{Fe}_{3} \mathrm{O}_{4} @ \mathrm{C} / \mathrm{CuNPs}$ & $0.08-372$ & 5 & This work \\
$\mathrm{Fe}_{3} \mathrm{O}_{4} @ \mathrm{C} / \mathrm{AuNPs}$ & $0.007-15$ & 5 & \\
\hline
\end{tabular}

relatively lower detection limit. In comparison with those previous works, the advantages of our work are ascribed to five aspects: (1) the combination of the magnetic core of $\mathrm{Fe}_{3} \mathrm{O}_{4}$, thin layer of $\mathrm{C}$, and uniformly dispersed AuNP modification shows their synergies and thus enhances the catalytic ability towards $\mathrm{H}_{2} \mathrm{O}_{2}$; (2) the $\mathrm{C}$ layer prevents $\mathrm{Fe}_{3} \mathrm{O}_{4}$ catalyst from aggregating and maintains its catalytic activity; (3) the utilization of magnetic electrode increases the modification amount of $\mathrm{Fe}_{3} \mathrm{O}_{4} @ \mathrm{C} / \mathrm{AuNP}$ and enhances the stability of the electrode modification; (4) the $\mathrm{C}$ layer is not compact, which facilitate $\mathrm{H}_{2} \mathrm{O}_{2}$ and the reaction products transferring between the bulk solution and electrode surface; and (5) the modification of AuNPs enhances the electron transfer and electrochemical activity of the $\mathrm{H}_{2} \mathrm{O}_{2}$ sensor.

3.5. Stability and Repeatability. The application of chemical sensors put forward higher demands on stability and catalytic signal repeatability. DPV and EIS measurements for $\mathrm{Fe}_{3} \mathrm{O}_{4} @ \mathrm{C} / \mathrm{AuNP}$-modified ITO were conducted in $0.1 \mathrm{M}$ of $\mathrm{pH} 7.4 \mathrm{PBS}$ containing $0.1 \mathrm{M} \mathrm{KCl}$ and $5 \mathrm{mM}[\mathrm{Fe}(\mathrm{CN}) 6]^{3-/ 4-}$. As shown in Figure 7, it was found that the DPV peak remained nearly unchanged after 10 cycles of scanning. On the other hand, the Nyquist plots nearly overlapped for 10 times of detection, and the $\mathrm{R}_{\mathrm{ct}}$ value maintained around $152 \Omega$. It demonstrated that the immobilized $\mathrm{Fe}_{3} \mathrm{O}_{4} @ \mathrm{C} /$ AuNP modification layer could keep a good level of stability in a continuous scanning system.

In addition, a repeated measurement towards $1 \mathrm{mM} \mathrm{H}_{2} \mathrm{O}_{2}$ in $0.1 \mathrm{M} \mathrm{pH} 7.4$ PBS was conducted to verify the repeatability of the sensor. The response signal recorded on 5 parallel electrodes is displayed in Figure 7(c), and the relative standard deviation (RSD) value between them was calculated as $1.8 \%$. The good stability and repeatability of the fabricated $\mathrm{H}_{2} \mathrm{O}_{2}$ sensor are attributed to the simple modification method, stable property, and good catalytic ability of $\mathrm{Fe}_{3} \mathrm{O}_{4} @ \mathrm{C} / \mathrm{AuNPs}$.

3.6. Interference Study. To evaluate the selectivity of $\mathrm{Fe}_{3} \mathrm{O}_{4} @ \mathrm{C} / \mathrm{AuNP}$, an interference study was carried out. As it is known, AA, UA, and CA are the most common interfering electroactive species during the detection of $\mathrm{H}_{2} \mathrm{O}_{2}$. The current responses with the addition of $\mathrm{H}_{2} \mathrm{O}_{2}$, 


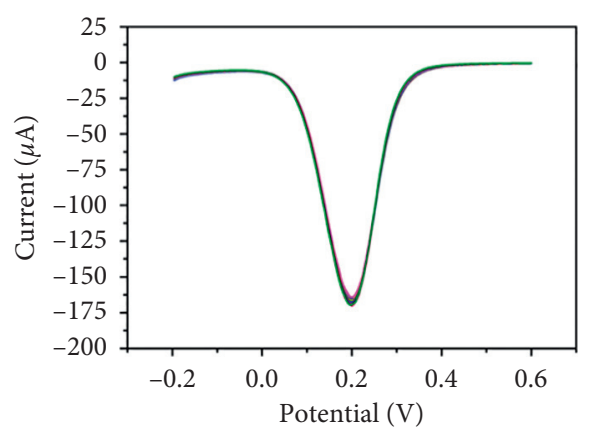

(a)

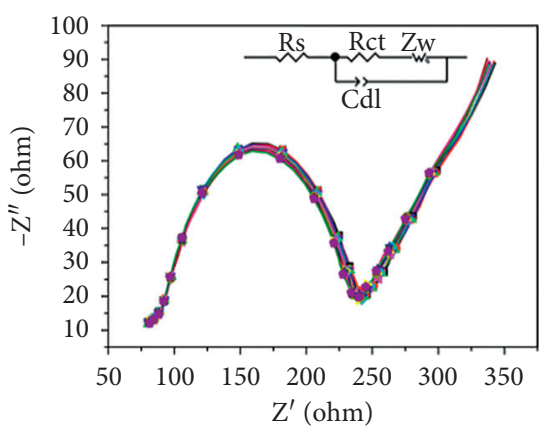

(b)

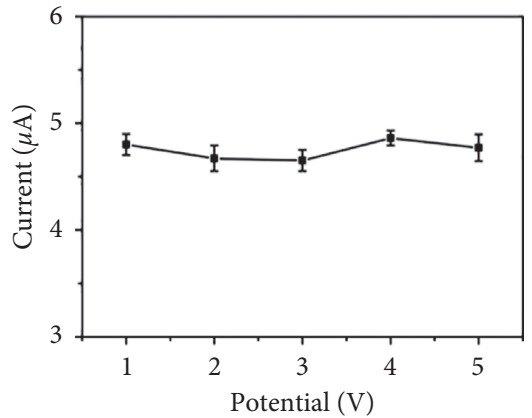

(c)

Figure 7: (a) DPV and (b) EIS curves of $\mathrm{Fe}_{3} \mathrm{O}_{4} @ \mathrm{C} / \mathrm{AuNP} / \mathrm{ITO}$ in $0.1 \mathrm{M}$ of $\mathrm{pH} 7.4 \mathrm{PBS}$ containing $0.1 \mathrm{M} \mathrm{KCl}$ and $5 \mathrm{mM}[\mathrm{Fe}(\mathrm{CN}) 6]^{3-/ 4-}$ with 10 continuous cycles of scanning. (c) The reduction peak current of $1 \mathrm{mM} \mathrm{H}_{2} \mathrm{O}_{2}$ in $0.1 \mathrm{M} \mathrm{pH} 7.4 \mathrm{PBS}$ recorded on 5 parallel sensors.

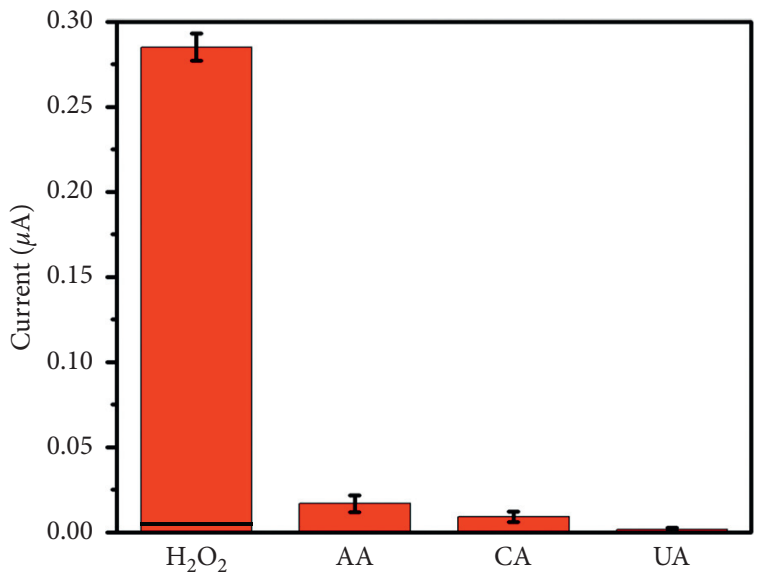

Figure 8: Current responses after addition of $0.1 \mathrm{mM}$ of $\mathrm{H}_{2} \mathrm{O}_{2}, \mathrm{AA}, \mathrm{UA}$, and CA at the potential of $-0.35 \mathrm{~V}$, respectively.

TABLE 2: The recovery of $\mathrm{H}_{2} \mathrm{O}_{2}$ by standard addition method in FBS samples.

\begin{tabular}{lccc}
\hline Sample & Added concentration $(\mathrm{mM})$ & Measured concentration $(\mathrm{mM})$ & Recovery $(\%)$ \\
\hline 1 & 0.094 & 0.09 & 95.14 \\
2 & 0.28 & 0.29 & 103.6 \\
3 & 0.47 & 0.48 & 102.1 \\
4 & 0.95 & 0.94 & 98.95 \\
5 & 4.54 & 4.62 & 101.8 \\
\hline
\end{tabular}

$\mathrm{AA}, \mathrm{UA}$, and $\mathrm{CA}$ at the potential of $-0.35 \mathrm{~V}$ are shown in Figure 8, among which the responses caused by AA, UA, and CA interfering species were no more than $10 \%$ response of $\mathrm{H}_{2} \mathrm{O}_{2}$. The result implied that the $\mathrm{Fe}_{3} \mathrm{O}_{4} @ \mathrm{C} /$ AuNPs possessed high selectivity for $\mathrm{H}_{2} \mathrm{O}_{2}$ detection at the potential of $-0.35 \mathrm{~V}$.

3.7. Determination of $\mathrm{H}_{2} \mathrm{O}_{2}$ in Fetal Bovine Serum (FBS). The determination of $\mathrm{H}_{2} \mathrm{O}_{2}$ in $\mathrm{FBS}$ was also investigated. The FBS was diluted with $0.1 \mathrm{M}$ of $\mathrm{pH} 7.4 \mathrm{PBS}$ via the volume ratio of $1: 9$. We measured the recovery by adding different concentrations of $\mathrm{H}_{2} \mathrm{O}_{2}$ into the FBS dilution. The recovery values were calculated ranging from 95.14 to $103.6 \%$, which are presented in Table 2. The relative standard deviations
(RSDs) are less than 5\%, proving a good application prospect.

\section{Conclusion}

In summary, a novel core-shell structured $\mathrm{Fe}_{3} \mathrm{O}_{4} @ \mathrm{C} / \mathrm{AuNPs}$ nanocomposite is successfully synthesized and utilized for fabricating a nonenzymatic $\mathrm{H}_{2} \mathrm{O}_{2}$ sensor, exhibiting a wider linear range from 0.007 to $15 \mathrm{mM}$ and a lower detection limit of $5 \mu \mathrm{M}$ with a sensitivity of $28.71 \mu \mathrm{A} \mathrm{mM}^{-1} \mathrm{~cm}^{-2}$. The advantages of the proposed sensor over the previous works are concluded as four points: (1) the superparamagnetic property of $\mathrm{Fe}_{3} \mathrm{O}_{4} @ \mathrm{C} / \mathrm{AuNP}$ nanocomposite contributes to the construction of a magnetic electrode modification, 
enhancing the stability of the sensor greatly. (2) The protection of C/AuNPs bilayer ensures the monodispersity of $\mathrm{Fe}_{3} \mathrm{O}_{4}$ catalyst, maintaining its good catalytic activity for $\mathrm{H}_{2} \mathrm{O}_{2}$ reduction. (3) The C/AuNPs bilayer possesses hydrophilicity, biocompatibility, electroactivity, and conductivity, facilitating the substance transmission and electron transfer between bulk solution and electrode surface. (4) The detection of $\mathrm{H}_{2} \mathrm{O}_{2}$ in FBS illustrates high selectivity, displaying good potential for real applications. Of course, the fabricated $\mathrm{Fe}_{3} \mathrm{O}_{4} @ \mathrm{C} / \mathrm{AuNPs}$ nanocomposite could also be used as substrate or nanolabel in other sensing systems.

\section{Data Availability}

The data that support the findings of this study are available from the corresponding author upon reasonable request.

\section{Conflicts of Interest}

The authors declare no conflicts of interest.

\section{Acknowledgments}

This work was financially supported by the National Natural Science Foundation of China (21575064), the Six Talent Peaks Project in Jiangsu Province (2016-SWYY-022), and the Qinglan Project of Jiangsu Education Department (2016).

\section{References}

[1] C.-L. Liang, Y. Liu, R.-Y. Bao et al., "Effects of $\mathrm{Fe}_{3} \mathrm{O}_{4}$ loading on the cycling performance of $\mathrm{Fe}_{3} \mathrm{O}_{4} / \mathrm{rGO}$ composite anode material for lithium ion batteries," Journal of Alloys and Compounds, vol. 678, pp. 80-86, 2016.

[2] H. Y. Aziz and S. G. Maryam, " $\mathrm{Fe}_{3} \mathrm{O}_{4} / \mathrm{ZnO} / \mathrm{Ag}_{3} \mathrm{VO}_{4} / \mathrm{AgI}$ nanocomposites: quaternary magnetic photocatalysts with excellent activity in degradation of water pollutants under visible light," Separation and Purification Technology, vol. 166, pp. 63-72, 2016.

[3] Y. Wang, Y. Lai, S. Wang, and W. Jiang, "Controlled synthesis and electromagnetic wave absorption properties of core-shell $\mathrm{Fe}_{3} \mathrm{O}_{4} @ \mathrm{SiO}_{2}$ nanospheres decorated graphene," Ceramics International, vol. 43, no. 2, pp. 1887-1894, 2017.

[4] A. M. Muliwa, T. Y. Leswifi, M. S. Onyango, and A. Maity, "Magnetic adsorption separation (MAS) process: an alternative method of extracting $\mathrm{Cr}(\mathrm{VI})$ from aqueous solution using polypyrrole coated $\mathrm{Fe}_{3} \mathrm{O}_{4}$ nanocomposites," Separation and Purification Technology, vol. 158, pp. 250-258, 2016.

[5] J. Chang, Q. Ma, J. Ma, and H. Ma, "Synthesis of $\mathrm{Fe}_{3} \mathrm{O}_{4}$ nanowire@ $\mathrm{CeO}_{2} / \mathrm{Ag}$ nanocomposites with enhanced photocatalytic activity under sunlight exposure," Ceramics International, vol. 42, no. 10, pp. 11827-11837, 2016.

[6] M. P. Kingsley, P. B. Desai, and A. K. Srivastava, "Simultaneous electro-catalytic oxidative determination of ascorbic acid and folic acid using $\mathrm{Fe}_{3} \mathrm{O}_{4}$ nanoparticles modified carbon paste electrode," Journal of Electroanalytical Chemistry, vol. 741, pp. 71-79, 2015.

[7] J. Qu, Y. Dong, T. Lou, and X. Du, "Determination of hydrogen peroxide using a novel sensor based on $\mathrm{Fe}_{3} \mathrm{O}_{4-}$ Magnetic nanoparticles," Analytical Letters, vol. 47, no. 11, pp. 1797-1807, 2014.
[8] J. Xie, H. Cao, H. Jiang et al., " $\mathrm{Co}_{3} \mathrm{O}_{4}$-reduced graphene oxide nanocomposite as an effective peroxidase mimetic and its application in visual biosensing of glucose," Analytica Chimica Acta, vol. 796, pp. 92-100, 2013.

[9] R. Tian, X. Chen, X. Xu, and C. Yao, "Electrocatalytic activity of core/shell magnetic nanocomposite," Analytical Biochemistry, vol. 463, pp. 45-53, 2014.

[10] H. Beitollahi, S. Tajik, and S. Jahani, "Electrocatalytic determination of hydrazine and phenol using a carbon paste electrode modified with Ionic Liquids and Magnetic Coreshell $\mathrm{Fe}_{3} \mathrm{O}_{4} @ \mathrm{SiO}_{2} / \mathrm{MWCNT}$ Nanocomposite," Electroanalysis, vol. 28, no. 5, pp. 1093-1099, 2016.

[11] J. Wang, J. Yang, X. Li et al., "Preparation and photocatalytic properties of magnetically reusable $\mathrm{Fe}_{3} \mathrm{O}_{4} @ \mathrm{ZnO}$ core/shell nanoparticles," Physica E: Low-Dimensional Systems and Nanostructures, vol. 75, pp. 66-71, 2016.

[12] A. Orhan, C. Aykut, K. Hilal, and S. Ozlem, "Dendrimer templated synthesis of carbon nanotube supported PdAu catalyst and its application as hydrogen peroxide sensor," Electroanalysis.vol. 31, pp. 1646-1655, 2019.

[13] C. K. Hilal, S. Firat, C. Aykut, K. Hilal, and A. Nahit, "Synthesis, characterization, and voltammetric hydrogen peroxide sensing on novel monometallic (Ag, Co/MWCNT) and bimetallic (AgCo/MWCNT) alloy nanoparticles," Fullerenes, Nanotubes and Carbon Nanostructures, vol. 26, pp. 145-151, 2018.

[14] W. Zhang, L. Y. Zhang, X. J. Zhao, and Z. Zhou, "Citrus pectin derived ultrasmall $\mathrm{Fe}_{3} \mathrm{O}_{4} @ \mathrm{C}$ nanoparticles as a high-performance adsorbent toward removal of methylene blue," Journal of Molecular Liquids, vol. 222, pp. 995-1002, 2016.

[15] C. Zhang, S. Si, and Z. Yang, "A highly selective photoelectrochemical biosensor for uric acid based on core-shell $\mathrm{Fe}_{3} \mathrm{O}_{4} @ \mathrm{C}$ nanoparticle and molecularly imprinted $\mathrm{TiO}_{2}$," Biosensors and Bioelectronics, vol. 65, pp. 115-120, 2015.

[16] J. Wei, S.-S. Li, Z. Guo, X. Chen, J.-H. Liu, and X.-J. Huang, "Adsorbent assisted in situ electrocatalysis: an ultra-sensitive detection of $\mathrm{As}(\mathrm{III})$ in water at $\mathrm{Fe}_{3} \mathrm{O}_{4}$ nanosphere densely decorated with Au nanoparticles," Analytical Chemistry, vol. 88, no. 2, pp. 1154-1161, 2016.

[17] J.-D. Qiu, M. Xiong, R.-P. Liang, H.-P. Peng, and F. Liu, "Synthesis and characterization of ferrocene modified $\mathrm{Fe}_{3} \mathrm{O}_{4} @$ $\mathrm{Au}$ magnetic nanoparticles and its application," Biosensors and Bioelectronics, vol. 24, no. 8, pp. 2649-2653, 2009.

[18] H. Wang, Q.-W. Chen, Y.-F. Yu, K. Cheng, and Y.-B. Sun, "Size- and solvent-dependent magnetically responsive optical diffraction of carbon-encapsulated superparamagnetic colloidal photonic crystals," The Journal of Physical Chemistry C, vol. 115, no. 23, pp. 11427-11434, 2011.

[19] X. Chen, J. Zhu, Z. Chen, C. Xu, Y. Wang, and C. Yao, “A novel bienzyme glucose biosensor based on three-layer $\mathrm{Au}$ $\mathrm{Fe}_{3} \mathrm{O}_{4} @ \mathrm{SiO}_{2}$ magnetic nanocomposite," Sensors and Actuators B: Chemical, vol. 159, no. 1, pp. 220-228, 2011.

[20] Q. Gao, F. Chen, J. Zhang et al., "The study of novel $\mathrm{Fe}_{3} \mathrm{O}_{4} @$ $\gamma-\mathrm{Fe}_{2} \mathrm{O}_{3}$ core/shell nanomaterials with improved properties," Journal of Magnetism and Magnetic Materials, vol. 321, no. 8, pp. 1052-1057, 2009.

[21] S. Xuan, Y.-X. J. Wang, J. C. Yu, and K. C.-F. Leung, "Preparation, characterization, and catalytic activity of core/ shell $\mathrm{Fe}_{3} \mathrm{O}_{4} @$ polyaniline@Au nanocomposites," Langmuir, vol. 25, no. 19, pp. 11835-11843, 2009.

[22] J. Gong, K. Yao, J. Liu et al., "Striking influence of $\mathrm{Fe}_{2} \mathrm{O}_{3}$ on the "catalytic carbonization" of chlorinated poly(vinyl chloride) into carbon microspheres with high performance in the 
photo-degradation of Congo red," Journal of Materials Chemistry A, vol. 1, no. 17, pp. 5247-5255, 2013.

[23] J. Zhang, Y. Ji, P. Wang, Q. Shao, Y. Li, and X. Huang, "Adsorbing and activating $\mathrm{N}_{2}$ on heterogeneous $\mathrm{Au}-\mathrm{Fe}_{3} \mathrm{O}_{4}$ nanoparticles for $\mathrm{N}_{2}$ fixation," Advanced Functional Materials, vol. 30, no. 4, Article ID 1906579, 2020.

[24] K. Liao, P. Mao, Y. Li et al., "A promising method for fabricating $\mathrm{Ag}$ nanoparticle modified nonenzyme hydrogen peroxide sensors," Sensors and Actuators B: Chemical, vol.181, pp. 125-129, 2013.

[25] H. Heli and J. Pishahang, "Cobalt oxide nanoparticles anchored to multiwalled carbon nanotubes: synthesis and application for enhanced electrocatalytic reaction and highly sensitive nonenzymatic detection of hydrogen peroxide," Electrochimica Acta, vol. 123, pp. 518-526, 2014.

[26] J. Wang, H. Gao, F. Sun, and C. Xu, "Nanoporous PtAu alloy as an electrochemical sensor for glucose and hydrogen peroxide," Sensors and Actuators B: Chemical, vol. 191, pp. 612-618, 2014.

[27] C. K. Hilal, C. Aykut, A. Tarik, A. Nahit, and K. Hilal, "Microstructured prealloyed Titanium-Nickel powder as a novel nonenzymatic hydrogen peroxide sensor," Journal of Colloid and Interface Science, vol. 530, pp. 353-360, 2018.

[28] D. K. Hilal, A. Tarik, and C. Aykut, "Electrochemical production of graphene oxide and its application as a novel hydrogen peroxide sensor," International Journal of Nano Dimension, vol. 10, pp. 252-259, 2009.

[29] X. Ke, Z. Li, L. Gan et al., "Three-dimensional nanoporous Au films as high-efficiency enzyme-free electrochemical sensors," Electrochimica Acta, vol. 170, pp. 337-342, 2015.

[30] Y. Li, J.-J. Zhang, J. Xuan, L.-P. Jiang, and J.-J. Zhu, "Fabrication of a novel nonenzymatic hydrogen peroxide sensor based on Se/Pt nanocomposites," Electrochemistry Communications, vol. 12, no. 6, pp. 777-780, 2010.

[31] S. N. Azizi, S. Ghasemi, and S. Kavian, "Synthesis and characterization of $\mathrm{NaX}$ nanozeolite using stem sweep as silica source and application of Ag-modified nanozeolite in electrocatalytic reduction of $\mathrm{H}_{2} \mathrm{O}_{2}$," Biosensors and Bioelectronics, vol. 62, pp. 1-7, 2014.

[32] E. Kurowska, A. Brzózka, M. Jarosz, G. D. Jaskuła, and M. Jaskuta, "Silver nanowire array sensor for sensitive and rapid detection of $\mathrm{H}_{2} \mathrm{O}_{2}$," Electrochimica Acta, vol. 104, pp. 439-447, 2013.

[33] J. B. Raoof, R. Ojani, E. Rashid-Nadimi, S. Hasheminejad, and S. Rashid-Nadimi, "Electrochemical synthesis of Ag nanoparticles supported on glassy carbon electrode by means of p-isopropyl calix[6]arene matrix and its application for electrocatalytic reduction of $\mathrm{H}_{2} \mathrm{O}_{2}$," Applied Surface Science, vol. 258, no. 7, pp. 2788-2795, 2012.

[34] M. Zhang, Q. Sheng, F. Nie, and J. Zheng, "Synthesis of Cu nanoparticles-loaded $\mathrm{Fe}_{3} \mathrm{O}_{4} @$ carbon core-shell nanocomposite and its application for electrochemical sensing of hydrogen peroxide," Journal of Electroanalytical Chemistry, vol. 730, pp. 10-15, 2014. 